2001s-39

\title{
Managing IT Outsourcing Risk: Lessons Learned
}

Benoit A. Aubert, Suzanne Rivard, Michel Patry

\begin{tabular}{c}
\hline Série Scientifique \\
Scientific Series
\end{tabular}

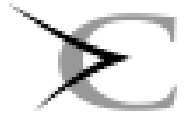




\section{CIRANO}

Le CIRANO est un organisme sans but lucratif constitué en vertu de la Loi des compagnies du Québec. Le financement de son infrastructure et de ses activités de recherche provient des cotisations de ses organisationsmembres, d'une subvention d'infrastructure du ministère de la Recherche, de la Science et de la Technologie, de même que des subventions et mandats obtenus par ses équipes de recherche.

CIRANO is a private non-profit organization incorporated under the Québec Companies Act. Its infrastructure and research activities are funded through fees paid by member organizations, an infrastructure grant from the Ministère de la Recherche, de la Science et de la Technologie, and grants and research mandates obtained by its research teams.

\section{Les organisations-partenaires / The Partner Organizations}

-École des Hautes Études Commerciales

-École Polytechnique

-Université Concordia

-Université de Montréal

-Université du Québec à Montréal

-Université Laval

-Université McGill

-Ministère des Finances du Québec

-MRST

-Alcan inc.

-AXA Canada

-Banque du Canada

- Banque Laurentienne du Canada

-Banque Nationale du Canada

-Banque Royale du Canada

-Bell Québec

-Bombardier

-Bourse de Montréal

-Développement des ressources humaines Canada (DRHC)

-Fédération des caisses populaires Desjardins de Montréal et de l'Ouest-du-Québec

-Hydro-Québec

-Imasco

-Industrie Canada

-Pratt \& Whitney Canada Inc.

-Raymond Chabot Grant Thornton

-Ville de Montréal

(C) 2001 Benoit A. Aubert, Suzanne Rivard et Michel Patry. Tous droits réservés. All rights reserved.

Reproduction partielle permise avec citation du document source, incluant la notice $\odot$.

Short sections may be quoted without explicit permission, if full credit, including $\odot$ notice, is given to the source.

Ce document est publié dans l'intention de rendre accessibles les résultats préliminaires

de la recherche effectuée au CIRANO, afin de susciter des échanges et des suggestions.

Les idées et les opinions émises sont sous l'unique responsabilité des auteurs, et ne représentent pas nécessairement les positions du CIRANO ou de ses partenaires.

This paper presents preliminary research carried out at CIRANO and aims at encouraging discussion and comment. The observations and viewpoints expressed are the sole responsibility of the authors. They do not necessarily represent positions of CIRANO or its partners. 


\title{
Managing IT Outsourcing Risk: Lessons Learned ${ }^{*}$
}

\author{
Benoit A. Aubert ${ }^{\dagger}$, Suzanne Rivard ${ }^{\dagger}$, Michel Patry ${ }^{\dagger}$ \\ Résumé / Abstract
}

Cet article fait un constat des leçons tirées de récentes analyses du risque d'impartition. Une définition opérationnelle du risque d'impartition est donnée. Les mécanismes de gestion de risque sont également discutés. Les résultats de différentes études démontrent qu'une gestion active du risque permet de réduire sensiblement les niveaux d'exposition au risque, notamment dans le cas de contrats d'impartition des technologies de l'information.

This document takes stock from several studies on outsourcing risk. A definition of risk is offered and illustration from many case studies is used to show how risk can be managed. Results show that an active risk management approach can reduce risk exposure subtantially while enabling the organizations to still reap the benefits associated with outsourcing.

Mots Clés : Impartition, gestion des risques, agence, coûts de transaction, décision, risque et incertitude

Keywords: Outsourcing of IS, IS risk management, agency theory, transaction cost economics, decision making under risk and uncertainty

\footnotetext{
* Corresponding Author: Benoit A. Aubert, CIRANO, 2020 University Street, $25^{\text {th }}$ floor, Montréal, Qc, Canada H3A 2A5 Tel.: (514) 985-4000 Fax: (514) 985-4039 email: aubertb@cirano.qc.ca

† École des Hautes Études Commerciales et CIRANO
} 


\section{Introduction}

"You'll never have all the information you need to make a decision - if you did, it would be a foregone conclusion, not a decision" (Mahoney, 1988, p.156).

Risk is inherent to almost any business decision. New product development, capital investments, and implementation of state of the art technology are often used as examples of risky business ventures; while they may lead to major benefits, they may also result in important losses. Outsourcing decisions, and contractual arrangements of the type required by an IT outsourcing deal, are another example of a risky business endeavor. While it can lead to lower costs, economies of scale, access to specialized resources, and new business ventures (Gupta and Gupta, 1992; Huff, 1991), outsourcing can have unwanted outcomes such as escalating costs, diminishing service levels, and loss of expertise, to name a few (Earl, 1996; Gack, 1994; Lacity and Hirschheim, 1993).

This is not to say that outsourcing is bad in itself. It only means that, as in other risky business ventures, risk assessment and risk management are important contributors to the success of an IT outsourcing venture (Rao, Nam and Chaudhury, 1996). During the past five years, we have conducted a number of studies on IT outsourcing in general (Aubert et al. 1996b, Aubert et al. 1999) and on IT outsourcing risk management in particular (Aubert et al. 1998; 1999; 2001). In this paper we draw upon this research to provide a synthesis of the main lessons on IT outsourcing risk and risk management we learned over the years.

The paper first defines the concepts of risk and of risk exposure and applies these definitions to the context of IT outsourcing risk. It then presents a framework of IT outsourcing risk exposure. Finally, it presents three case studies, each of which lead to a different set of lessons learned on how firms actually manage IT outsourcing risk.

\section{Risk Defined}

Risk and risk management have been studied in many domains, such as Insurance, Economics, Management, Medicine, Operations Research, and Engineering. Each field addresses risk in a fashion relevant to its object of analysis, hence, adopting different perspectives of risk and of risk management. Since it is essential that the conceptualization of risk and of risk management adopted in a study be consistent, authors ought to clearly state the perspective they are adopting in their study of risk. This section reviews the main perspectives of risk and of risk management adopted in various fields, and then presents the perspective we adopted to study IT outsourcing risk and risk management.

Risk as an undesirable event. In some situations, risk is equated to a possible negative event. Levin and Schneider (1997; p. 38) defines risks as “... events that, if they occur, represent a material threat to an entity's fortune”. Using this definition, risks are the multiple undesirable events that may occur. Applied in a management context, the "entity" would be the organization. Given that perspective, risks can be managed using insurance, therefore compensating the entity if the event occurs; they can also be managed using contingency planning, thus providing a path to follow if an undesirable event occurs. This definition of risk is analogous to the concept of risk as a possible reduction of utility discussed by Arrow (1983). 
Risk as a probability function. Some fields, instead of focusing on negative events, are primarily concerned with the probabilities of an event. For example, medicine often focuses solely on the probability of disease (e.g. heart attack), since the negative consequence is death in many cases. It would be useless to focus on the consequence itself since it is irreversible. Odds of occurrence are the key element. Data is used to determine what can influence those probabilities (heredity, smoking habits, cholesterol level, etc.). In its definition of sentinel events (occurrence involving death or serious injury), the Joint Commission on the Accreditation of Healthcare Organizations uses "risk" as the chance of serious adverse outcome (Kobs, 1998).

Life insurance adopts this approach and uses mortality tables to evaluate these probabilities. In this context, a "good risk" will be a person with a low probability of dying within a given period (and hence, for the insurance company, a low probability of having to pay a compensation) and a "bad risk" would be a person with a high probability of dying within the period.

Risk as variance. Finance adopts a different perspective of risk, where risk is equated to the variance of the distribution of outcomes. The extent of the variability in results (whether positive of negative) is the measure of risk. Risk is defined as the volatility of a portfolio's value (Levine, 2000). Risk management means arbitrating between risk and returns. For a given rate of return, managers will prefer lower volatility but would be likely to tolerate higher volatility if the expected return was thought to be superior. Portfolio managers therefore aim to build a portfolio that is on the efficient frontier, meaning it has "the highest expected return for a given level of risk, and the lowest level of risk for a given expected return” (Schirripa and Tecotzky, 2000; p. 30).

Risk as expected loss. Other fields, such as casualty insurance, adopt a perspective of risk as expected loss. They define risk as the product of two functions: a loss function and a probability function. Car insurance is a good example. In the eventuality of an accident, there is a loss function that represents the extent of the damages to the car, which can range from very little damage to the total loss of the car. There is also a probability function that represents the odds that an incident will occur. The expected loss (risk) is the product of these two functions (Bowers et al. 1986).

While in certain circumstances, the probability of occurrence of an undesirable outcome can be estimated on the basis of past performance characteristics of the object under study (LineroothBayer and Wahlstrom, 1991), in several areas, probabilities are often difficult, if not impossible to assess on the basis of past performance (Barki, Rivard, and Talbot, 1993). Consequently, several risk assessment methods adopt the approach of approximating the probability of undesirable outcomes by identifying and assessing factors that influence their occurrence (Anderson and Narasimhan,1979; Boehm, 1991; Barki et al., 1993). In a software development context, for instance, Barki et al. [5] have identified such factors, which belong to five broad categories: technological newness, application size, software development team's lack of expertise, application complexity, and organizational environment. The degree to which each factor is present in a software project will contribute to increase the probability of occurrence of an undesirable outcome (here, project failure). Once this list is drawn, risk management methods try simultaneously to reduce the loss related to the undesirable event itself (such as penalties compensating for delays in the system delivery) or by reducing the probability of occurrence of such an event, by reducing the level of the risk factors (for example, by carefully selecting team members). While the definition of risk is not explicit about probability distribution, these 
probabilities (taking the form of factors) are taken into account when the risk evaluation is performed.

\section{Endogenous and Exogenous Risk}

Another important distinction in risk analysis is the notion of endogenous versus exogenous risk. Exogenous risks are risks over which we have no control and which are not affected by our actions. Earthquakes or hurricanes are good example of exogenous risks. Although we have some control over the extent of damage by selecting construction standards, we have no control over the occurrence of such natural events. Endogenous risks, on the other hand, are risks that are dependent on our actions. Car accident is an example of risk where a strong portion is endogenous. While a driver has no control over other drivers (the exogenous portion), the probability of an accident is strongly influenced by the driver's behavior and ability (endogenous). The driver also controls part of the loss function, by deciding to drive an expensive car or a cheap car. This is why there is always a deductible amount with car insurance, to ensure that the driver will behave in a way that will minimize the endogenous portion of the risk. By being responsible of a portion of the damages, the driver is enticed to act with caution.

Risk management tools take into account whether risk is endogenous or exogenous. In finance for example, risk is considered exogenous. The methods used to manage risk are concerned with diversification, insurance, and allocation of assets. There is no direct action that managers can take to reduce the probability of a given event. In engineering or medicine, a portion of the risk is always endogenous. Risk management takes it into account. Patients are informed of the portion they control and are proposed more healthy diets and lifestyles, employees are provided with security guidelines and actions are taken to reduce directly the probability of undesirable consequences.

\section{IT Outsourcing Risk}

Our study of IT outsourcing risk management uses the expected loss perspective. When referring to the set of specific risks to which the firm is exposed, we will use the term risk exposure. Risk exposure is therefore defined as:

$$
\mathbf{R E}=\boldsymbol{\Sigma}_{\mathrm{i}} \mathbf{P}\left(\mathbf{U} \mathbf{O}_{\mathrm{i}}\right) * \mathbf{L}\left(\mathbf{U} \mathbf{O}_{\mathrm{i}}\right)
$$

where $\mathrm{P}\left(\mathrm{UO}_{\mathrm{i}}\right)$ the probability of an undesirable outcome $i$, and $\mathrm{L}\left(\mathrm{UO}_{\mathrm{i}}\right)$ the loss due to the undesirable outcome $i$ (Boehm, 1991; Teece et al, 1994). Therefore, we are considering simultaneously the potential losses associated with an outsourcing contract and the probability function of such losses.

It is important to note that only the negative side of the distribution of all potential events is considered in this definition of risk. Positive events are not considered. This approach is justified for many reasons. The main reasons are the overly positive attitude of managers entering in outsourcing contracts and the managerial perception of risk. These two reasons are briefly discussed in the following paragraphs.

Managers making decisions with respect to IT and outsourcing are often overly optimistic (Hirschheim and Lacity, 2000). They take their decision to outsource based on a best case scenario. There also seems to be an inflation about reported outsourcing benefits (Saunders, Gebelt and $\mathrm{Hu}$, 1997) which probably sustains this optimism. This overly confident view of the 
managers when entering into a contractual relationship is in itself a sufficient reason to consider only the potential downsides of the contract when evaluating outsourcing risk. If managers based their analysis on a best case scenario, the only unpredictable events that can occur are undesirable. This may explain why, in the 61 outsourcing decisions reported by Lacity and Willcocks (1998), 56\% of the managers indicated that expected cost savings were realized, 23\% mentioned that expectations were not met while $21 \%$ could not tell. No one reported that cost savings exceeded expectations. This is a typical result when decisions are made according to a best case scenario, at the positive end of the possible outcome distribution.

This behaviour is consistent with the managerial perception of risk. March and Shapira (1987, p.1407)) reported that "Possibilities for gain are of primary significance in assessing the attractiveness of alternatives (MacCrimmon and Wehrung, 1986), but "risk" is seen as associated with the negative outcomes." In this sense, the behaviour of managers in weighing up outsourcing decisions is similar to generic manager's behaviour.

\section{Assessing IT Outsourcing Risk Exposure}

While theoretically risk exposure can be computed and a value of risk established in dollar terms, in practice it is more useful to map the risk exposure on a two-dimension plane (the usefulness of this representation will be discussed in the risk management sub-section). Figure 1 illustrates the mapping of risk exposure.

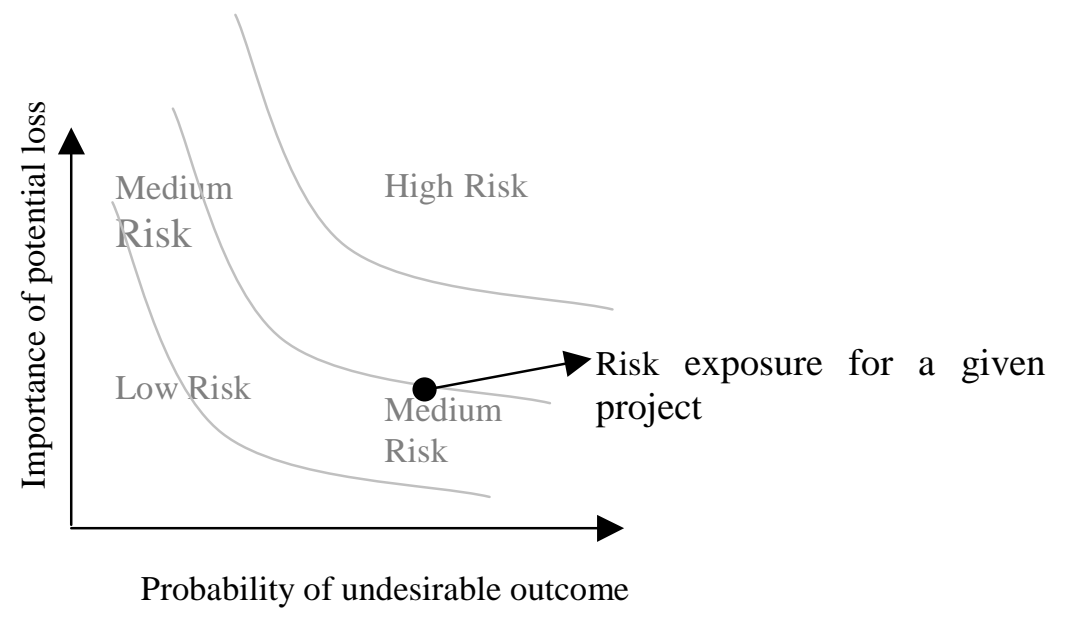

Figure 1: Risk exposure

To evaluate risk exposure, it is therefore essential to identify the array of potential undesirable outcomes that could occur with respect to an outsourcing arrangement, as well as the probability of occurrence of such outcomes. In any situation, several undesirable outcomes may occur. The loss due to a given undesirable outcome can be approximated either via quantitative analysis (for instance, by evaluating the amount of sales lost due to disruption of service to customers) or via qualitative assessment of the organizational impact of each negative outcome (by using Likert scales to assess the importance of the impact of the undesirable outcome). The probability of 
undesirable outcomes is assessed by identifying and measuring the factors that influence their occurrence.

The risk assessment framework relies mostly on Transaction Cost and Agency theories. These tackle directly the problems related to contracting and provide both a roadmap to potential negative consequences and their corresponding drivers (risk factors). A complete description of the theoretical background was given in Aubert et al. (1998). The following paragraphs briefly summarize the gist of the argument.

\section{Foundations of Contractual Risk}

Fundamentally, outsourcing is a contract in which a client relies on a supplier for a given service, instead of depending on internal provision. In this case, the client relies on the market rather than on employment contracts.

According to transaction costs theory, the decision to use the market to regulate a transaction will depend on: the specificity of the assets, the uncertainty surrounding the transaction, and the frequency of the transaction. The specificity of an asset creates a lock-in situation where a party could extract a quasi-rent from the contracting party by threatening to withdraw from the transaction. The usual manner to resolve the asset specificity constraint is to use long term contracts. However, uncertainty may preclude contract agreement since the parties cannot predict what will be needed in the future and, consequently, cannot write a contract (Williamson 1985, 1989). Severe measurement problems might also prevent contractual agreement since it becomes impossible to know if performance is attributable to one party's action or to externalities (Alchian and Demsetz, 1972). All contract provisions, to alleviate these problems, make contracting more costly. When these costs are too high, it might be cheaper to purchase the residual rights over the activities in exchange of a salary (Grossman and Hart, 1986). This contract enables one party (the employer) to choose, in the future, the actions appropriate to the context (Simon, 1991). Finally, a firm will prefer to bear the cost of the risk associated with specific investment or uncertainty rather than to invest in order to internalize a single transaction. Internal organization is only efficient for frequent transactions.

Agency theory is concerned with the client's problem to choose an agent (outsourcer), motivate it and coordinate its decisions and behavior with those of the organization. The client wants the outsourcer to perform its tasks as required. However, writing and enforcing complete contracts is utopia. The agency costs include the cost of writing and enforcing contractual agreements and the residual loss resulting from inadequate coordination or motivation. Agency theory tackles the important issue of designing efficient contractual agreements (Eisenhardt, 1989).

Agency theory generally distinguishes three main villains: moral hazard, adverse selection, and imperfect commitment. Moral hazard stems from the fact that it is impossible for a principal to observe an agent's behaviour at no cost. Since it cannot tell, and since the supplier knows this, the supplier can always blame poor performance on circumstances beyond its control. Cheating, shirking, free-riding, cost padding, exploiting a partner, or simply being negligent are everyday instances of moral hazard. Adverse selection will develop when the principal cannot observe the characteristics of the agent. Failure to deal adequately with adverse selection will make it very difficult for the client to choose the right supplier. The last potentially damaging manifestation of opportunism is imperfect commitment. For instance, clients and outsourcers may be tempted 
to renege on their promises and commitments, arguing unforeseen events like changes in requirements (Sappington, 1991).

Using this theoretical framework, a list of potential negative outcomes and associated risk factors has been developed and validated using case studies (Aubert et al, 1999, 2001). The potential negative outcomes are related to three main categories: service, costs (of various forms), and externalities.

\section{Potential Negative Outcomes}

Under the service label, two problematic situations can occur: the services delivered do not correspond to the ones the company needs or the service are of poor quality. The first case usually occurs when the company, after establishing in a detailed contract the services to be delivered, changes its needs over time. Then the services required differ from the ones stipulated in the contact. This leads to a negative consequence: costly contractual amendments. In the latter case, the services might be the appropriate ones, but their quality is not up to expectations. It is important to note that these problems can occur with internal provision. However, since the employment contract is more flexible than a market contract, services can be readjusted more easily when service is delivered in-house.

The second main category pertains to costs. Clients can face costs that were not anticipated: there can be transition and management costs that make the contract less profitable than anticipated. Switching costs (preventing repatriation or transfer to another supplier) can be built over time, and finally, the costs of the services themselves can escalate.

Finally the client can face two main indirect consequences. The first one is a loss of competences. By relying on external provision, the organization will stop nurturing some competences. When these competences are close to the core competencies of the organization, such loss might threaten future organization action (Roy and Aubert, 2000). The other potential treat is the possibility of disputes and litigation. While haggling is not in the mind of organizations when they negotiate their contracts, such occurrence is always possible.

\section{Risk Factors}

The above mentioned potential consequences do not occur randomly. Many factors play a role in increasing their probability of occurrence. As mentioned earlier, these factors are drawn in a large measure from Transaction Cost, Agency and Incomplete Contract Theories. They can be grouped into three main categories: the principal, the agent, and the transaction itself. These elements all deal with market failure. The clients themselves are often a major risk factor. They key characteristics to consider with respect with the client are linked to knowledge: experience and expertise with the activities outsourced, and with outsourcing contracts. The other element to consider is the culture of the organization, to ensure a cultural fit with the supplier. Also, many characteristics of the suppliers should be considered. First, its experience and expertise with both the activities handled and the management of outsourcing contract is critical. Second, the supplier size, its financial stability and its culture. The number of suppliers is also a concern. A client facing a thin market will increase the risk of lock-in. Finally, the transaction itself, namely the activities chosen for outsourcing, is a key component of risk exposure. As transaction cost theory indicates, activities that are uncertainty, difficult to measure, or that involve the use of specific assets present higher chances of leading to contractual problems (Williamson, 1985). 
Activities that are complex and intertwined with the rest of organization activities (high interdependence) also increase the chances of problems, so will a contract of a very large scope.

These outcomes, with their associated factors, are summarized in Table 1. The outcomes are presented with the factors presenting the strongest effect on the probability of occurrence of each outcome. This does not imply that other factors cannot have an influence on a give outcome, it simply means that these are the critical factors.

\section{Table 1. Components of IT outsourcing risk exposure (Adapted from Table 1 - Aubert et al. 2001, p.2)}

\begin{tabular}{|c|c|}
\hline Undesirable outcomes & Factors leading to outcome \\
\hline $\begin{array}{l}\text { Unexpected transition } \\
\text { and management costs } \\
\text { (Cross, 1995; Earl, } \\
\text { 1996; Nelson et al, } \\
\text { 1996) }\end{array}$ & $\begin{array}{l}\text { - Lack of experience and expertise of the client with the activity } \\
\text { (Earl, 1996; Lacity et al, 1995) } \\
\text { - Lack of experience of the client with outsourcing (Earl, 1996) } \\
\text { - Uncertainty about the legal environment }\end{array}$ \\
\hline $\begin{array}{l}\text { Switching costs } \\
\text { (including lock-in, } \\
\text { repatriation and } \\
\text { transfer to another } \\
\text { supplier) (O'Leary, } \\
\text { 1990) }\end{array}$ & $\begin{array}{ll}\text { - } & \text { Asset specificity (Williamson, 1985) } \\
\text { - } & \text { Small number of suppliers (Nam et al. 1996) } \\
\text { - } & \text { Scope } \\
\text { - } & \text { Interdependence of activities }\end{array}$ \\
\hline $\begin{array}{l}\text { Costly contractual } \\
\text { amendments (Earl, } \\
1996)\end{array}$ & $\begin{array}{ll}\text { - } & \text { Uncertainty (Alchian and Demsetz, 1972; Barzel, 1982) } \\
\text { - } & \text { Technological discontinuity (Lacity et al. 1995) } \\
\text { - } & \text { Task complexity }\end{array}$ \\
\hline $\begin{array}{l}\text { Disputes and litigation } \\
\text { (Aubert et al. 1997b; } \\
\text { Lacity and Hirschheim, } \\
\text { 1993) }\end{array}$ & $\begin{array}{l}\text { - Measurement problems (Alchian and Demsetz, 1972; Barzel, 1982) } \\
\text { - Lack of experience and expertise of the client and/or of the supplier } \\
\text { with outsourcing contracts (Earl, 1996; Lacity et al, 1995) } \\
\text { - Uncertainty about the legal environment } \\
\text { - Poor cultural fit }\end{array}$ \\
\hline $\begin{array}{l}\text { Service debasement } \\
\text { (Lacity and } \\
\text { Hirschheim, 1993) }\end{array}$ & $\begin{array}{l}\text { - Interdependence of activities (Aubert et al. 1997; Langlois and } \\
\text { - } \\
\text { - Labertson, 1992) } \\
\text { (Earl, 1996) } \\
\text { - Supplier size (Earl, 1996) } \\
\text { - Supplier financial stability (Earl, } 1996 \text { ) } \\
\text { - } \text { Teasurement problems (Alchian and Demsetz, 1972; Barzel, 1982) } \\
\text { Task complexity }\end{array}$ \\
\hline $\begin{array}{l}\text { Cost escalation (Lacity } \\
\text { and Hirschheim, 1993; } \\
\text { Lacity et al, 1995) }\end{array}$ & $\begin{array}{l}\text { - Lack of experience and expertise of the client with contract } \\
\text { management (Earl, 1996; Lacity et al, 1995) } \\
\text { - Measurement problems (Alchian and Demsetz, 1972; Barzel, 1982) } \\
\text { - Lack of experience and expertise of the supplier with the activity } \\
\text { (Earl, 1996) }\end{array}$ \\
\hline
\end{tabular}


Table 1 - cont'd

\begin{tabular}{l|ll}
\hline Undesirable outcomes & Factors leading to outcome \\
\hline $\begin{array}{l}\text { Loss of organizational } \\
\text { competencies [Dorn, }\end{array}$ & $\bullet$ & Scope \\
$\begin{array}{l}\text { 1989; Earl, 1996; } \\
\text { Lacity et al, 1995] }\end{array}$ & $\bullet$ & Interdependence of activities \\
\hline $\begin{array}{l}\text { Hidden Service Costs } \\
\text { (Lacity and }\end{array}$ & $\bullet \quad$ Complexity of the activities \\
Hirschheim, 1993) & $\bullet \quad$ Measurement problems (Alchian and Demsetz) \\
\hline
\end{tabular}

The objective of risk management is to reduce the level of risk exposure of a given business venture. Given an expected level of benefits from an outsourcing strategy, a rational, profit maximizing, and risk-averse decision maker wishes to minimize the risk exposure of the project or the strategy. A bounded rational decision maker may wish, for the same given level of benefits, to bring the level of risk exposure below some threshold or acceptable level (this is a "satisfying" decision rule, in Herbert Simon's terminology ). In both cases, reduction of the level of risk exposure can be achieved in two ways: either by reducing the losses associated with the undesirable outcomes, or by lowering the expected probability of occurrence of such outcomes.

\section{The Case Studies}

In order to better understand and analyze how IT outsourcing risk was managed in organizations, case studies were conducted in three different firms. For each firm, data were collected on one or several outsourcing decisions, from the following sources: requests for proposals, supplier proposals, contracts and addenda, and interviews with managers who had been involved in the decision process and managers in charge of overseeing the contracts. Using this data, each researcher independently assessed the risk level of each outsourcing decision, by rating the risk factors and the undesirable outcomes listed in Table 1. The impact of each outcome was assessed on a 1 (very low) to 7 (very high) scale. Then, the probability of occurrence of each outcome was approximated (on a 1 to 7 scale) by first evaluating each of the risk factors associated with the outcome and then by aggregating the values of all the factors. The independent assessments were then compared and discussed, until a final assessment was agreed upon.

The cases illustrate three different dimensions of IT outsourcing risk management. The first case shows the importance of using a formal risk measure and explicitly assessing risk. The second exemplifies how risk management is the result of a series of compromises. Organizations reducing a risk often increase another one. It is a matter of selecting the risks you are willing to take. Finally, the third example is an epitome of risk management. An example in which the client had the resources and the knowledge to negotiate a contract with an impressive array of risk management mechanisms. Since a detailed description of each case is provided elsewhere, details about the cases are omitted below.

\section{Managers Attitude Toward Risk}

The first case is that of GVDL, a large insurance company. Two system development outsourcing decisions and the resulting contracts were analyzed : the Year 2000 project and the 
Application development partnership project (see Aubert et al. 1999). The first project was the Y2K conversion of the legacy system. The estimated effort required for migrating all the systems through the millennium was more than 25000 person-days. The second project was called the Application development partnership project. The firm had decided to stop awarding contracts to many different suppliers and to select a single (or maybe a few) application partner that would invest time and resources in understanding the company and its needs. The results of the assessment of risk exposure for these two outsourcing decisions are presented in Figure 2 (black icons represent initial risk levels).

From Figure 2, it seems quite clear that project $1(\mathrm{Y} 2 \mathrm{~K})$ was less risky that project 2 . While many potential consequences (service debasement, lock-in and cost escalation) had high values for project 1, the probabilities were generally very low, with the exception of cost escalation, which was fairly probable. Project 2 was riskier. Items 3,6, and 7 have mid-range probabilities of occurrence and the losses associated with both lock-in and contractual amendments would be very high. The organization took several measures to lower the risk exposure associated with both contracts.

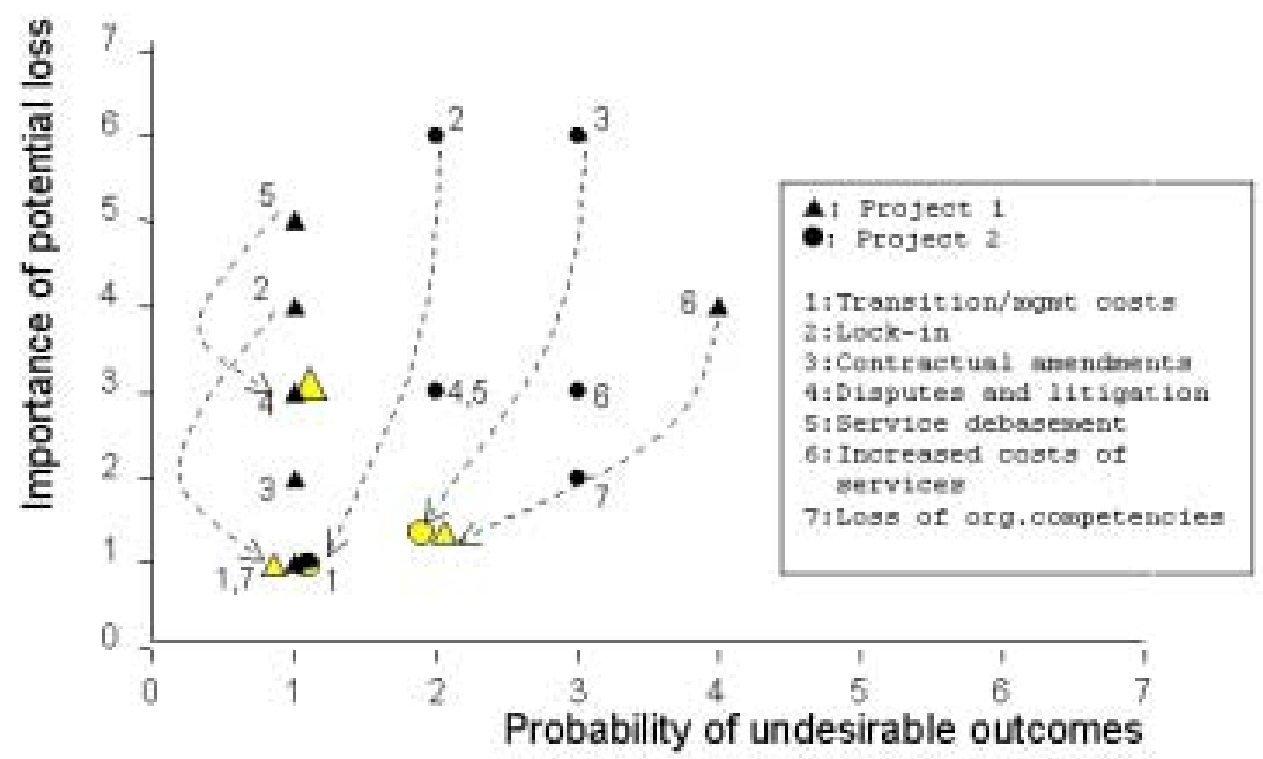

Figure 2: Insurance Company

In the Y2K contract, protection against lock-in was sought through sequential contracting. By splitting the work to be done in many sequential steps, the client ties the duration of the contract to verifiable performance on the one hand and leaves open the possibility of walking out of the relationship if things were to take a bad turn. In the case of service debasement, the main mechanism used by the client to reduce the probability of occurrence of this outcome was the inclusion of an important penalty for underperformance. This penalty was equal to five times the total value of the contract. Doing so elicits greater efforts from the supplier and serves as a type of insurance, thus reducing the monetary value of the consequences. Finally, in view of cost escalation, the client secured guaranteed rates and the parties agreed ex ante on the evaluation 
method and relied on a detailed inventory of the various components, languages, platforms, size, complexity, testing environments, interactions with other systems, etc. As shown by the arrows drawn in Figure 2, the potential losses associated with lock-in, service debasement and cost escalation are reduced.

In the second contract, the risk exposure stemming from lock-in was reduced in two ways. The first one is multiple sourcing: three were selected to work concurrently, which seriously curtails the probability of being locked-in for the client. Renegotiation problems and costly contractual amendments are handled through the separation of assignments in addenda. This enables the partners to actually modify their contract without costly renegotiations. It is an ongoing modification process that is included in the contract (sequential contracting). Risk is greatly reduced.

Among the interesting facts from this case is the perception of the managers. From Figure 2, it is quite clear that project 2 was riskier than project 1, whether one considers the risk before or after the risk management mechanisms are introduced. This result greatly surprised the managers. Their initial impression was that risk exposure was much greater with their project Y2K than with the partnership one. They agreed with the results presented in Figure 2 and realized that their evaluation was inaccurate. Their mistaken evaluation is coherent with remarks made by March and Shapira (1987). Managers perceived risk because some potential losses were high, failing to recognize that the probabilities of such losses (in project 1) were dim. Another factor was the time frame of both project. Consequences from problems with project one were almost immediate (January 2000). On the other hand, project 2 was a long term venture and many potential negative consequences will only unfold in a 2-5 year horizon. This might explain why project 2 was perceived as less risky. The risks involved were not recognized because they were too distant.

\section{Lessons Learned}

This case teaches us three main lessons. First, conducting a formal assessment of risk exposure, and mapping explicitly the risk exposure associated with a contract enables efficient risk management. Managers can immediately target the elements presenting high risk exposure and implement risk management mechanisms (while it was not used here, a drastic mechanism is to keep the activity in-house). Second, such explicit chart of risk exposure offers a remedy to some managers' biases. In this case, managers failed to recognize potential threats that were not in an immediate future. Their evaluation of events with very low probabilities was also biased. Third, by comparing projects and ordering them more accurately in terms of risk exposure, the organization can manage its outsourcing portfolio more effectively and ensure that efforts in risk management are allocated where they are the most profitable.

\section{Risk Management as a Series of Compromises}

The second case study was conducted at British Petroleum (BP). This case illustrates how risk management and learning can eventually transform risk into a "choice" rather than a "fate" (Aubert et al., 2001). British Petroleum, has extensive outsourcing experience, and a history of risk evaluation and management. The company employs more than 50,000 people and conducts worldwide activities. Two contracts are compared. The first one, labeled BPX, involved the outsourcing of IT activities linked to BP Exploration division (Cross, 1995). The second contract

- BP Global - concerns the whole IT organization (head office and divisions). 
First contract. The first contract was BP's first major outsourcing venture, covering data centre management, telecommunications, maintenance, and systems development. Risk exposure was high (see Figure 3). Because of the extent of the contracts, hidden service costs was the major threat. The main feature of the contract, in terms of risk management, was to rely on a consortium of three vendors to supply the services. Also, the contractual framework enabled $\mathrm{BPX}$ to renegotiate several clauses annually, further reducing this risk.

Disputes and litigations, costly contractual amendments, and loss of organizational competencies were next in order of importance in terms of risk exposure. BPX recognised that disagreements would probably arise both between the suppliers themselves and between them and BPX. BPX tried to reduce the impacts of disputes and litigation but uncovered that European antitrust laws prevented the three suppliers from joining in a formal alliance as originally planned. Given the type of contract selected (multiple sourcing), contractual amendments and contract renegotiation would presumably be limited the portfolio of activities of one of the supplier, limiting the extent of changes. Loss of innovative capacity (competencies) was considered the biggest potential loss resulting from moving so many staff out of the organization, especially since BPX had decided to become a knowledge organization. Again, the consortium was the means whereby BPX could reduce this risk because several suppliers would give access to a broader array of innovative services (and knowledge) than a single supplier. However, no supplier would have the big picture of the industry and the technology portfolio.

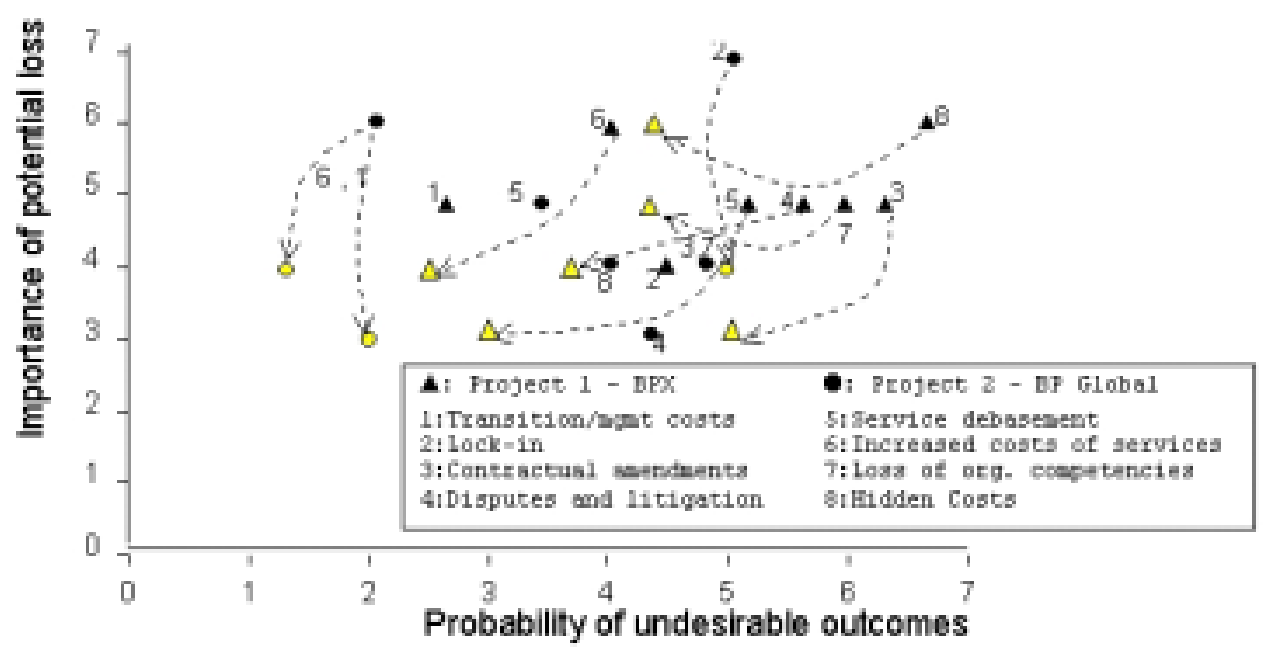

Figure 3: British Petroleum

(Reprinted from Aubert et al. 2001)

Second Contract. In 1998, BP changed its outsourcing strategy radically and decided that a single supplier would replace the fragmented assortment of suppliers which existed. BP evaluated that only two suppliers in the world were capable of providing services on such a scale. Therefore, a costly lock-in situation could easily appear To reduce potential problems due to the lock-in situation, BP included a one-year notice of termination, to help reduce the impact of a potential lock-in. Other elements where potential negative consequences are high are cost escalation and transition costs. The factors linked to cost escalation suggest a low probability of 
occurrence. BP has an extensive expertise and experience with outsourcing, the supplier is very experienced with the activities included in the contract and is very competent in managing contractual relationships. The most threatening factor is the presence of measurement problems. One of the tools to reduce them will be benchmarking, which will be conduced on a regular basis. Transition costs could also bring severe penalties. They would come with service deterioration and business disruption. Transferring activities to EDS presents different risks in different regulatory situations (different countries). To reduce the transition related problems, BP increased the planning efforts in a wide variety of aspects. Interestingly, the overall cost of transition is not necessarily reduced, but the unexpected part of it is.

\section{Lessons Learned}

The BP case provides two lessons. First, it is clear that learning occurred through the management of the BPX contract, which translated into both lower probabilities for the undesirable consequences and better risk management strategies in the second contract. Many of the contractual choices were made with less naivety. Managers were more realistic about potential loopholes in the arrangements and more aware of the limits of contracts. A key decision in the second contract was to remove software development from the arrangement. Development activities are more uncertain, more specific, and more complex than operations. By keeping them outside the portfolio of outsourced activities, the BP managers reduced the probabilities of occurrence of several undesirable consequences.

The second lesson is the notion that risk is a choice. The case showed that risk profiles can be seen as compromises. A given risk management mechanism could lower one type of risk while increasing another one. For example, when BP decided in the third contract to deal with a single supplier, risks related to measurement problems were less probable. However, this was done at the expense of an increase in the risk of lock-in. As managers become more aware of the control they have on the risk profile of their IT outsourcing strategy, they should bear more responsibility over the outcomes.

\section{Risk Management and Contract Design}

The last lessons come from the outsourcing contract of Niagara (name changed) (Aubert et al., 1997b). Niagara is a large Canadian Crown corporation, employing more than 50,000 people, with an annual income of over $\$ 5$ billion. It concluded a complex outsourcing arrangement with three suppliers. When it decided to outsource its IT services, the organization was extensively developing new software (1000 persons full-time) and having a hard time doing so. Although Niagara recognized that IT could radically change the way it did business, IT and software development were not within the core of Niagara competencies. The organization had problems hiring and retaining IT people. It was dealing with a vast number of consultants, without taking advantage of the consultants distinctive skills. Finally, Niagara had the feeling that some of the software solutions developed were innovative and could be sold to other similar organizations in the world. However, it did not have the skills nor the infrastructure to do so. Selling software was not its business.

The risk involved with outsourcing all the IT services, as was intended, was high (see Figure 4). Lock-in was the most important threat. Because of the sheer size of the contract, lock-in could be very costly. The probability of a lock-in was also high, mostly because of the specific nature of the software developed, and the limited number of suppliers that could handle such a large 
contract. Hidden costs were also to feared. The complexity of the activities, the number of different systems to integrate and the scope of the contract made hidden costs a likely menace. Similarly, cost escalation and costly contractual amendments would lead to severe losses. In the case of such a large contract, it would be tempting for a supplier to argue higher than expected costs and renege on the promised fees. Changes to any contract would also be probable because of the wide variety of services and the level of innovation in the field.

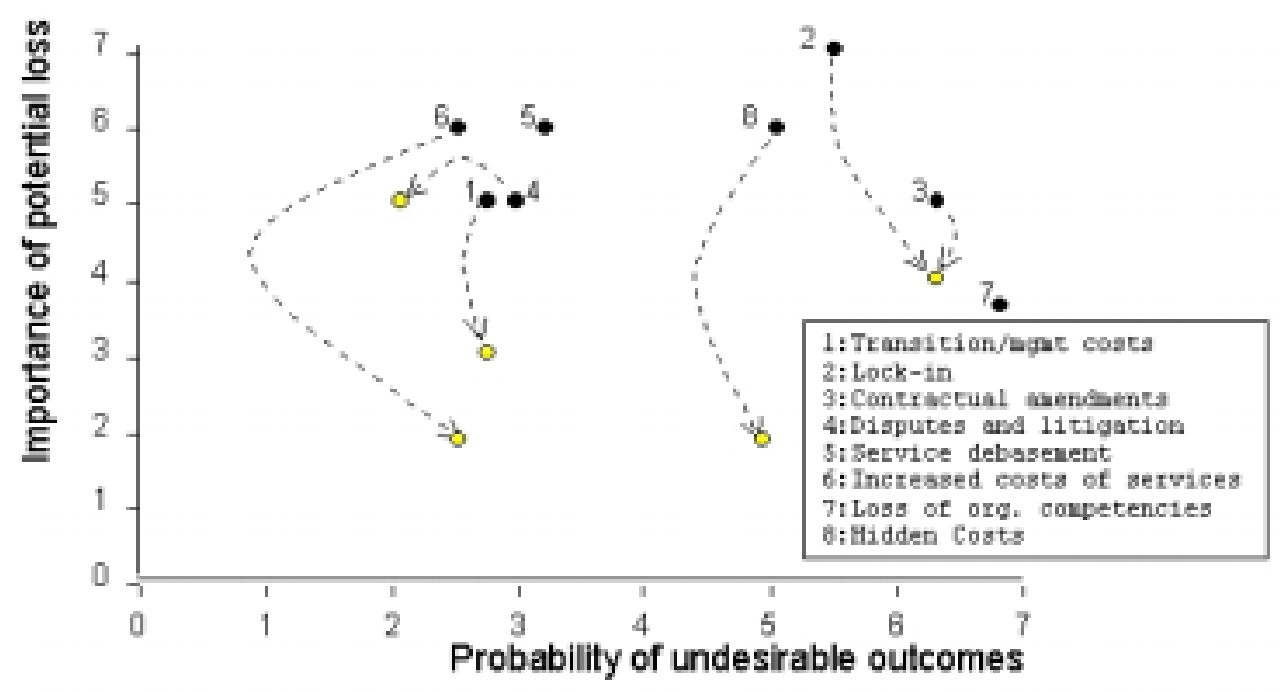

Figure 4: Niagara

Niagara had some precious resources when considering outsourcing. Most notably, the organization has a long tradition of measurement. Every activity in the organization is measured, and the organization had impressive charts and data about the resources required for developing or operating software. They had measurement guidelines for all types of application, based on the vast number of projects done by the organization or sub-contracted. They had enough internal data to benchmark potential suppliers.

Niagara finally signed an original deal, integrating several risk management mechanisms. They decided to use three suppliers. Each one was responsible for a given portfolio of activities and had an area of responsibility. The outsourcing contracts placed the three outsourcers in the unusual situation of having to cooperate and/or compete on almost every project. They had a group of activities allotted to them. For any new project, Niagara asked one of the three a cost estimate. This estimate was compared to internal ones and, if acceptable, the contract could be given without further delay. If unsatisfactory, Niagara could ask the other suppliers to bid. External bids could also be sought. The three suppliers were preferred because they had a much better knowledge of the organization. They still had to remain honest to retain their share of the overall IT activities.

Another element of interest was the outside deals. The suppliers had the infrastructure to sell outside Canada the software developed. The outsourcing deal established a joint venture between Niagara and its suppliers to do so. At the time the case was written, they were transferring its technology to eight countries. Neither the client nor the outsourcers would have had the capacity, 
alone, to market that technology. The reputation of Niagara and the skills of the suppliers were essential elements in the success of the joint sales venture abroad. These external deals were extremely attractive for the outsourcers. While they were a source of revenue, they also served as great goal alignment mechanisms between Niagara and its suppliers, reducing potential "cultural" differences at the same time. They acted as a bond, guaranteeing satisfactory service to the client.

The competition between the suppliers reduced the expected losses associated with hidden costs and cost escalation. So did the benchmarking. Before undertaking a new software project, key indicators such as cost per milestone, total development cost, elapsed time, and total cost minus fixed assets, were used to assess it. These parameters were clearly specified ex ante so the suppliers knew how they were being evaluated. Activities were measured on a regular basis, graphing the number and types of problems, their category according to security level, and their overall impact. Also, by separating the portfolio into three parts, any cost escalation due to opportunistic behaviour of a supplier would be limited to a third of the overall portfolio.

Cost escalation was also limited by the use of countervailing incentives. In their dealing with Niagara, the outsourcers were responsible for the maintenance of the systems they had developed. Consequently, they had a strong incentive to develop efficient systems, so as to minimize their maintenance efforts. Linking two stages of production can provide an incentive for an agent to perform in the principal's interest. When two stages of production are not independent an agent may be motivated to perform better if it is responsible for both stages. By putting extra effort into the first stage, it will reduce the effort required at the subsequent stage. Inversely, by shirking during the first stage, it will increase the effort required later. The result is that the agent cannot claim to have made an excessive effort at both stages.

Monitoring was used extensively to reduce the risk of service debasement. Each deliverable done by a supplier had to be approved by one of the two other supplier. Once a piece of work was approved, the supplier approving the work became responsible for its judgment (and for handling the costs related to problems). An interesting result of this type of arrangement was that Niagara automatically obtained a third party view of each supplier's work.

\section{Lessons Learned}

This case teaches two lessons. First, risk can be managed and efficient contract design can drastically reduce risk. In many ways, Niagara was able to implement several of the features that British Petroleum wanted to include in its first contract. Because the regulatory regime in Canada is different than the European one, there were no obstacle to such contract design. One key element of this contract is that risk is not eliminated, it is mostly transferred to the suppliers. They become responsible for many of the potential negative events that can occur. They are positioned in a way that makes them guardians of the other suppliers on behalf of Niagara. Such risk taking is unusual for the suppliers. When Niagara proposed this agreement to several potential suppliers, many declined to bid. This further reduced the number of potential suppliers, which explain why they probability of lock-in increased (while the potential loss decreased because of the dividing of the portfolio into three parts).

The other lesson is that size does matter. This sophisticated contract would not have been possible if the portfolio of activities had been smaller. The suppliers agreed to enter into this relationship because they expected to make money. They accepted to shoulder more risk than 
they usually do because they anticipated greater benefits. Each one dedicated approximately 350 employees to the contract with Niagara. Moreover, the outside deals were a powerful incentive. These other contracts made the relationship with Niagara especially precious and guaranteed the client that suppliers would not threaten this relationship. All this apparel is only justifiable if the size of the contract is significant.

\section{Conclusion}

The cases reported here support the proposed risk assessment framework and justify its use when considering outsourcing. First, it helps correct some of the manager's biases. It is difficult to compare different alternatives that are associated with both probability distributions and different loss functions. The human mind can only deal with a limited number of scenarios and a formal analysis ensures that all key elements are taken into account.

The cases also support the notion that risk is a choice. This is especially true when risk is largely endogenous, like with outsourcing risk. Managers have a choice between different sourcing strategies, and numerous contracts for any given activity. By selecting any one of them, they have to realize what they are selecting and what they are discarding. Risk exposure, once made explicit, transforms the unexpected into an option selected consciously. These selections are always compromises. Most risk management mechanisms involve reducing some types of risk while increasing other, or accepting to pay a fee to reduce a given risk.

Finally, once risk exposure is explicit, and the possible compromises clear to the managers, risk becomes a lot more manageable. Not surprisingly, organizations with a lot of resources, awarding larger contracts, will have more flexibility when managing their risk portfolio and more possibilities to reduce their risk exposure. 


\section{References}

Alchian, A.A., Demsetz, H., "Production, Information Cost and Economic Organization," American Economic Review, 62, December 1972, pp. 777-795.

Anderson, J., Narasimhan, R., "Assessing Implementation Risk : A Methodological Approach," Management Science, Vol.25, No.6, June 1979, pp. 512-521.

Arrow, Kenneth, "Behaviour Under Uncertainty and its Implications for Policy", in Foundations of Utility and Risk Theory with Applications, Bernt Stigurn and Fred Wenslop editors, Reidel Publishing Company, Dordrecht, Holland, 1983, 19-34.

Aubert, B.A., Dussault, S., Patry, M., Rivard, S., "Managing the Risk of IT Outsourcing, " Proceedings of the Thirty-Second Hawaii International Conference on System Sciences, Organizational Systems and Technology Track, Hugh Watson editor, Hawaii, 1999 (CDROM).

Aubert, Benoit, Patry, Michel, Rivard, Suzanne, "The Outsourcing of IT: Autonomous Versus Systemic Activities", 28th Annual Meeting of the Decision Sciences Institute, (Nov. 97), San Diego, CA D. Olson Editor, Volume 2, pp. 809-812.

Aubert, B.A., Patry M., Rivard, S., "Assessing the Risk of IT Outsourcing" Proceedings of the Thirty-First Hawaii International Conference on System Sciences, Volume VI, Organizational Systems and Technology Track, Hugh Watson editor, Hawaii, 1998, 685-693.

Aubert, B.A., Patry, M., Rivard, S., "A Tale of Two Outsourcing Contracts," Cahier du GReSI 97-05, 1997b.

Aubert, Benoit A., Patry, Michel, Rivard, Suzanne, Chapter 3.3 Impartition des services informatiques au Canada: Une comparaison 1993-1997, Impartition Fondements et analyse, Michel Poitevin editor, Presses de l'université Laval (1999) 203-220.

Aubert, Benoit A., Patry, Michel, Rivard, Suzanne, Smith, Heather, IT Outsourcing Risk Management at British Petroleum, 34th Hawaii International Conference on Systems Sciences, Organizational Systems and Technology Track, Hugh Watson editor, IEEE, Hawaii, January 5-8 2001.

Aubert, Benoit A., Rivard, Suzanne, Patry Michel, "A Transaction Cost Approach to Outsourcing Behavior: Some Empirical Evidence”, Information and Management. Vol. 30, (1996) 51-64.

Aubert, Benoit A., Rivard, Suzanne, Patry Michel, "Development of Measures to Assess Dimensions of IS Operation Transactions", Omega, International Journal of Management Science, Vol. 24, No. 6, (1996b) 661-680.

Barki, H., Rivard, S., Talbot, J., "Toward an Assessment of Software Development Risk," Journal of Management Information Systems, Vol. 10, No. 2, Fall 1993, pp. 203-225.

Barzel, Y., "Measurement Cost and the Organization of Markets,"Journal of Law and Economics, 25, April 1982, pp. 27-48.

Boehm, B, B.W., Software Risk Management, IEEE Computer Society Press, Los Alamitos, California, 1989. 
Bowers, L.N; Gerber, U.H; Hickman, C.J; Jones, A.D and Nesbit, J.C. "Actuarial Mathematics", The Society of Actuaries, 1986.

Cross, J., "IT Outsourcing: British Petroleum's Competitive Approach," Harvard Business Review, May-June 1995, pp. 95-102.

DiRomualdo, A., Gurbaxani, V., "Strategic Intent for IT Outsourcing", Sloan Management Review, Summer 1998, 67-80.

Dorn, P. "Selling One’s Birthright," Information Week, No.241, October 16, 1989, p. 52.

Earl, M.J., "The Risks of Outsourcing IT," Sloan Management Review, Spring 1996, pp. 26-32.

Eisenhardt, K. "Agency Theory: An Assessment and Review," Academy of Management Review, vol. 14, no. 1, 1989, pp. 57-74.

Gack, G., "A Cautionary Tale," Computerworld, September 12, 1994, pp. 136-136.

Grossman, S., Hart, O., "The Costs and Benefits of Ownership :A Theory of Vertical and Lateral Integration, " Journal of Political Economy, 94, 1986, pp. 691-719.

Gupta, U., Gupta, A., "Outsourcing the IS Function : Is It Necessray for your Organization ? ," Information Systems Management, Summer 1992, pp. 44-50.

Hirschheim, Rudy, Lacity, Mary, The Myths and Realities of Information Technology Insourcing, Communication of the ACM, February 2000, vol. 43, No. 2, 99-107.

Huff, S. L., "Outsourcing of Information Services," Business Quarterly, Spring 1991, pp. 62-65.

Kobs, Ann, Sentinel Events - A Moment in Time, A Lifetime to Forget, Nursing Management, February 1998, 10-13.

Lacity, M.C., Hirschheim, R., Information Systems Outsourcing, John Wiley \& Sons, New York, 1993.

Lacity, Mary, Willcocks, Leslie, An empirical Investigation of Information Technology Sourcing Practices: Lessons from Experience, MIS Quarterly, September 1998, 363-408.

Lacity, M.C., Willcocks, L.P., Feeny, D.F., "IT Outsourcing : Maximize Flexibility and Control," Harvard Business Review, May-June 1995, pp.84-93.

Langlois, R.N., Robertson, P.L., "Networks and Innovation in a Modular System: Lessons from the Microcomputer and Stereo Component Industries", Research Policy, vol. 21, 1992, pp. 297-313.

Levin, M., Schneider, M., "Making the Distinction: Risk Management, Risk Exposure”, Risk Management, August 1997, 36-42.

Levine, Elliott, "Defining Risks", CA Magazine, April 2000. 45-46.

Linerooth-Bayer, J., Wahlstrom, B., "Applications of Probabilistic Risk Assessments : the selection of Appropriate Tools," Risk Analysis, Vol.11, No.2, 1991, pp. 239-248.

Loh, L., Venkatraman, N., "Diffusion of Information Technology Outsourcing: Influence Sources and the Kodak Effect", ISR, volume 3, no. 4, (December 1992), 334-378 ; p. 336. 
MacCrimmon, Kenneth, Wehrung, Donald, Taking Risks: The Management of Uncertainty, Free Press, New York, 1986 (cited in March and Shapira, 1987).

Mahoney, D., Confessions of a Street-Smart Manager, New York : Simon \& Shuster, 1988.

March, J., Shapira, Z., "Managerial Perspectives on Risk and Risk-Taking," Management Science, Vol.33, No.11, pp. 1404-1418.

Nam, K., Rajagopalan, S., Rao, H.R., Chaudhury, A., "A Two-Level Investigation of Information Systems Outsourcing," Communications of the ACM, Vol.39, No.7, July 1996, pp. 37-44.

Nelson, P., Richmond, W., Seidman, A., "Two Dimensions of Software Acquisition," Communications of the ACM, Vol.39, No.7, July 1996, pp. 29-35.

O'Leary, M., "The Mainframe Doesn't Work Here Anymore," CIO, Vol.6, No.6, June 1990, pp. 77-79.

Prahalad, C.V., Hamel, G., "The Core Competence of the Corporation," Harvard Business Review, May-June 1990, 79-91.

Rao, H. R., Nam, K., Chaudhury, A., "Information Systems Outsourcing," Communications of the ACM, Vol.39, No.7, July 1996, pp. 27, 28.

Roy, Vital; Aubert, Benoit A.; "A Resource Based View of the Information Systems Sourcing Mode", Proceedings of the 33rd Hawaii International Conference on Systems Sciences, Organizational Systems and Technology Track, Hugh Watson editor, IEEE, Maui, Hawaii, Janvier 4-7 2000, (CD ROM).

Sappington, D. "Incentives in Principal-agent Relationships," Journal of Economic Perspectives, vol. 5, no. 2, Spring 1991, pp. 45-68.

Saunders, Carol, Gebelt, Mary, Hu, Qing, Achieving Success in Information Systems Outsourcing, California management Review, Vol. 39, No. 2, Winter 1997, 63-79.

Schirripa, Felix, Tecotzky, Nan, An Optimal Frontier, The Journal of Portfolio Management, Summer 2000, 29-40.

Simon, Herbert A., Organizations and Markets, Journal of Economic Perspectives, volume 5 no 2, (Spring 1991), 25-44.

Smith, Subramanian, Nauss, and Beck Developing Outsourcing Strategies for MIS: A mathematical Programming Approach, Proceedings of the Thirty-Four Hawaii International Conference on System Sciences, Organizational Systems and Technology Track, Hugh Watson editor, Hawaii, 2001 (CDROM).

Teece, D. J., Rumelt, R., Dosi, G., Winter S., "Understanding Corporate Coherence, Theory and Evidence", Journal of Economic Behavior and Organization, 23, 1994, 1-30

Williamson, O.E., The Economic Institutions of Capitalism, The Free Press, New York, 1985.

Williamson, Oliver, E., "Transaction Costs Economics", Handbook of Industrial Organization, R. Schmalensee and R.D. Willig, Vol. 1, (1989), 136-178. 


\section{Liste des publications au CIRANO*}

Série Scientifique / Scientific Series (ISSN 1198-8177)

2001s-38 Organizational Design of R\&D Activities / Stefan Ambec et Michel Poitevin

2001s-37 Environmental Policy, Public Interest and Political Market / Georges A. Tanguay, Paul Lanoie et Jérôme Moreau

2001s-36 Wealth Distribution, Entrepreneurship and Intertemporal Trade / Sanjay Banerji et Ngo Van Long

2001s-35 Comparaison des politiques de rémunération en fonction des stratégies organisationnelles / Michel Tremblay et Denis Chênevert

2001s-34 Déterminants et efficacité des stratégies de rémunération : Une étude internationale des entreprises à forte intensité technologique / Michel Tremblay, Denis Chênevert et Bruno Sire

2001s-33 La multiplicité des ancres de carrière chez les ingénieurs québécois: impacts sur les cheminements et le succès de carrière / Yvon Martineau, Thierry Wils et Michel Tremblay

2001s-32 The Impact of Interface Quality on Trust in Web Retailers / Marie-Christine Roy, Olivier Dewit et Benoit A. Aubert

2001s-31 R\&D and Patents: Which Way Does the Causality Run? / Hans van Ophem, Erik Brouwer, Alfred Kleinknecht and Pierre Mohnen

2001s-30 Contracting under Ex Post Moral Hazard and Non-Commitment / M. Martin Boyer

2001s-29 Project Financing when the Principal Cannot Commit / M. Martin Boyer

2001s-28 Complementarities in Innovation Policy / Pierre Mohnen et Lars-Hendrick Röller

2001s-27 Bankruptcy Cost, Financial Structure and Technological Flexibility Choices / Marcel Boyer, Armel Jacques et Michel Moreaux

2001s-26 Inflation as a Strategic Response / M. Martin Boyer et Pierre Thomas Léger

2001s-25 Simulation-Based Finite-Sample Tests for Heteroskedasticity and ARCH Effects / Jean-Marie Dufour, Lynda Khalaf, Jean-Thomas Bernard et Ian Genest

2001s-24 The Role of Organizational Commitment and Citizenship Behaviors in Understanding Relations between Human Resources Practices and Turnover Intentions of IT Personnel / Guy Paré, Michel Tremblay et Patrick Lalonde

2001s-23 A Resource-Based Analysis of Outsourcing: Evidence from Case Studies / Vital Roy et Benoit Aubert

2001s-22 Short and Long Memory in Equilibrium Interest Rate Dynamics / Jin-Chuan Duan et Kris Jacobs

2001s-21 Unemployment Insurance and Subsequent Job Duration: Job Matching vs Unobserved Heterogeneity / Christian Belzil

2001s-20 Estimating the Intergenerational Education Correlation from a Dynamic Programming Model / Christian Belzil et Jörgen Hansen

* Consultez la liste complète des publications du CIRANO et les publications elles-mêmes sur notre site Internet : 